\title{
MEDIAL MORAINES AND SURFACE MELT ON GLACIERS OF THE TORNGAT MOUNTAINS, NORTHERN LABRADOR, CANADA
}

\author{
By R.J. Rogerson, M.E. Olson, and D. BRANSON \\ (Departments of Earth Sciences and Geography, Memorial University of Newfoundland, \\ St. John's, Newfoundland A1B 3X5, Canada)
}

\begin{abstract}
Avalanche-type" medial moraines are described on four Torngat Mountains glaciers with single, rather than compound, firn basins. They form from debris avalanching down couloirs and are exposed by ice melt to form extensive debris covers on glacier snouts in the Torngat Mountains. The debris may play an important part in helping the glacier survive periods with warm summers and/or dry winters since, in the Torngat Mountains, average ice melt on debris-covered sites is approximately one-third that on exposed ice.
\end{abstract}

RÉsumé. Les moraines médianes et la fusion de surface sur des glaciers des Torngat Mountains, Labrador Septentrional, Canada. Des moraines médianes de type avalanche sont décrites pour quatre glaciers des Torngat Mountains avec des bassins d'accumulation uniques plutôt que composés. Elles se forment par les débris d'avalanches à la base des couloirs et par suite de la fusion de la glace elles développent d'épaisses couvertures de débris sur les

\section{INTRODUCTION}

Medial moraines, including longitudinal moraines (Lliboutry, 1965), inner moraines (Salisbury, 1894), and other variants, are important elements in the debris-transport system of mountain glaciers (Eyles and Rogerson, 1978[b]). They usually substantially decrease surface melt, and consequently have a major effect on the mass-balance of glaciers by protecting the ice surface from atmospheric warmth (Ogilvie, 1904; Sharp, 1949; Östrem, 1959; Loomis, 1970; Drewry, 1972).

Eyles and Rogerson (1978[a]) reviewed earlier research on medial moraines and outlined some models of medial moraine formation from field investigations on glaciers in Norway and Canada. Two major models were described and subsequently expanded (Rogerson and Eyles, 1979) to include two variants. One major type, called the "ablation-dominant model", is initiated by debris fall and sub-surface erosion at junctions below or above the firn line. Subsequently, moraine morphology in the ablation zone is a function of the nature of englacial sediment supply. The other model, called "ice-stream interaction model", is formed below the firn line by confluent lateral moraines.

Small and others (1979) described medial moraines on Alpine glaciers in Switzerland which are either variants within the "ablation-dominant" type, or may be regarded as "avalanche type", a third and minor model described by Rogerson and Eyles (1979). The significance of the "avalanche type" is that it is not necessarily formed at ice-stream or firn-basin junctions, but is related to couloirs or avalanche gullies. These may also be major suppliers of snow to the accumulation basin. Such moraines cannot be traced up-glacier to a point of junction; the moraine instead may be central to a single flow unit all the way from its point of origin. Furthermore, the "avalanche type" may form langues des Torngat Mountains. Ces débris peuvent jouer un rôle important en aidant le glacier à survivre aux périodes d'étés chauds et d'hivers secs, puisque dans ces montagnes la moyenne de la fonte sur glacier couvert est à peu près le tiers de ce quelle est en glace nue.

ZUSAMMENFASSUng. Mittelmoränen und Abschmelzung an der Oberfläche auf Gletschern der Torngat Mountains, NordLabrador, Kanada. Es werden Mittelmorănen vom "Lawinentyp" auf vier Gletschern der Torngat Mountains, die meist einzelne, nicht zusammenhängende Firnbecken aufweisen, beschrieben. Sie entstehen aus Schutt, der aus Felsrinnen herunterstürzt, und treten durch Eisabschmelzung zutage, um ausgedehnte Schuttdecken auf Gletscherzungen in den Torngat Mountains zu bilden. Der Schutt dürfte eine wichtige Rolle bei der Erhaltung der Gletscher in Perioden mit warmen Sommern und/oder trockenen Wintern spielen, denn in den Torngat Mountains beträgt die. Eisschmelze an schuttbedeckten Stellen etwa ein Drittel derer auf unbedecktem Eis.

in glaciers which are not compound, but consist of a single flow unit. In describing similar moraines, Lliboutry (1965) used the term "moraines longitudinales" and suggested they should be regarded as distinct from medial moraines. Small and others (1979) used the term "type C" to refer to the moraines which are closest in origin to the "avalanche type", although it is clear from their accompanying diagrams that they regarded compound glacier morphologies to be essential to their formation. Their medial moraine sources are always identified as points of confluence.

In this paper we describe the morphology and formation of medial moraines on simple and compound cirque glaciers in the Torngat Mountains of northern Labrador. There, moraines are fed primarily from avalanche gullies above the firn line and appear in the ablation zone as septa which are frequently unrelated to the junctions of ice streams. In the ablation zone, debris from the "avalanche-type" moraines spreads and mixes with that from other types of medial moraines to form an almost continuous cover over the termini of many of the glaciers.

Since medial moraines owe much of their surface expression to the modification of surface melt conditions, measurements of ice melt in the lower part of one glacier are presented from the summer of 1983 when the massbalance programme was augmented by a detailed examination of surface melt (Branson, unpublished).

\section{GLACIERS IN THE TORNGAT MOUNTAINS}

The Torngat Mountains are the highest on the eastern mainland of Canada, rising to a height of $1738 \mathrm{~m}$ at Mount Caubvick in the Selamiut Range. Over 70 small glaciers exist in the mountains, shaded in deep cirques for the most part and seldom greater than $1 \mathrm{~km}^{2}$ in area. Field investigations of four glaciers south of Nachvak Fiord and in the 
vicinity of the Selamiut Range began in 1981. As a part of the mass-balance programme, observations of the extent and morphology of supraglacial sediment cover provide the information for this description and analysis of medial moraines.

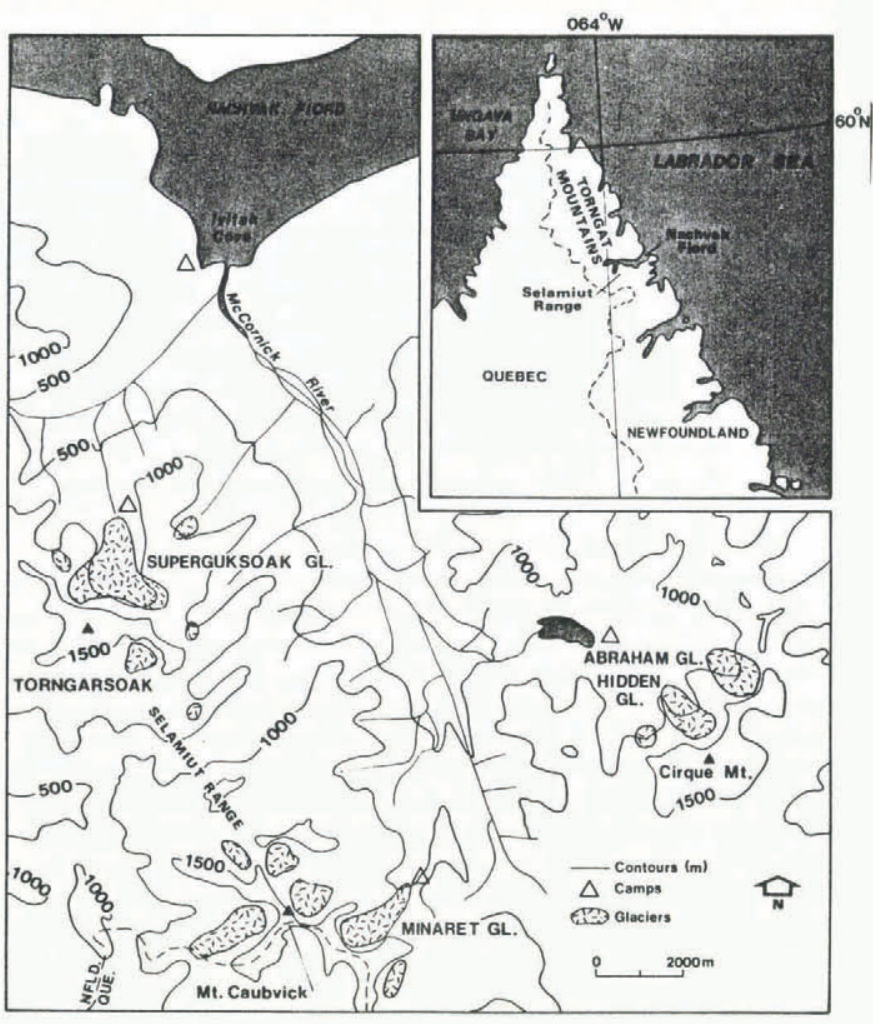

Fig. 1. Glaciers in the Selamiut Range and Cirque Mountain area, northern Labrador.
The four glaciers studied are unofficially named "Superguksoak" and "Minaret" in the Selamiut Range and "Hidden" and "Abraham" on the northern flanks of Cirque Mountain to the east of the Selamiut Range (Fig. 1). Superguksoak Glacier, the largest in the Torngat Mountains (approximately $1.4 \mathrm{~km}^{2}$ ) is the only one which may be considered compound in form, consisting of a single glacier tongue fed by two distinct accumulation basins which coalesce above the firn line (Fig. 2). The zone of junction between the two basins is indistinct. Within each basin several couloirs feed snow and avalanche debris to the body of firn. Preliminary results from a survey by radio echosounder in the summer of 1984 indicate that ice thickness is over $170 \mathrm{~m}$ in the vicinity of stake 100 (Fig. 2), while between stakes 10 and 30 it varies from 65 to $80 \mathrm{~m}$. The terminus of Superguksoak Glacier lies only $650 \mathrm{~m}$ a.s.1., while those for Abraham and Hidden Glaciers are approximately $700 \mathrm{~m}$ and $800 \mathrm{~m}$ a.s.l., and the terminus of Minaret Glacier is approximately $1000 \mathrm{~m}$ a.s.l. (Fig. 3) Three of the accumulation basins have similar mean elevations, rising to a maximum between 1000 and $1200 \mathrm{~m}$ a.s. 1 . The fourth, Minaret Glacier, lies almost entirely above the others in elevation with the major part of its accumulation basin over $1300 \mathrm{~m}$ a.s.1.

The glaciers experienced generally negative mass balances between 1981 and 1984, although both Minaret Glacier (the one with the highest altitudinal distribution) and Superguksoak Glacier (the one with the most extensive supraglacial debris cover) were slightly positive in 1982 .

Superguksoak, Hidden, and Abraham Glaciers all lie within deep cirques, open generally towards the north, with rock walls between 350 and $600 \mathrm{~m}$ in height. Minaret Glacier lies in a shallower cirque, the walls of which rise only $100 \mathrm{~m}$ above the southern margin of the glacier. Supraglacial sediment on Superguksoak Glacier covers a very large proportion of the glacier below the firn line. In the case of Minaret Glacier, sediment is restricted to the western margin of the terminus. Nevertheless, the debris is virtually all derived from medial moraines on all four glaciers and only on Superguksoak Glacier, with its

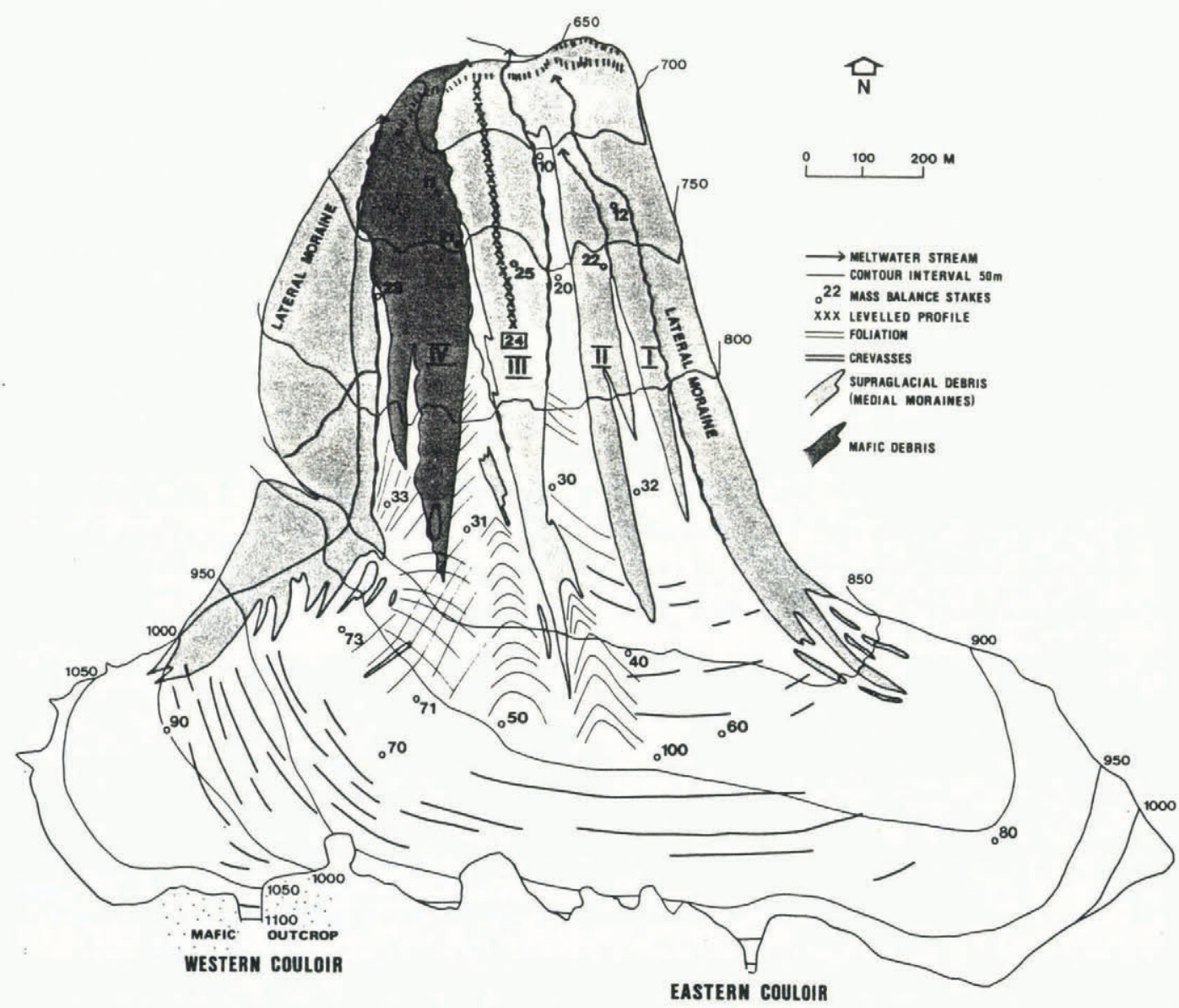

Fig. 2. Map of Superguksoak Glacier. 

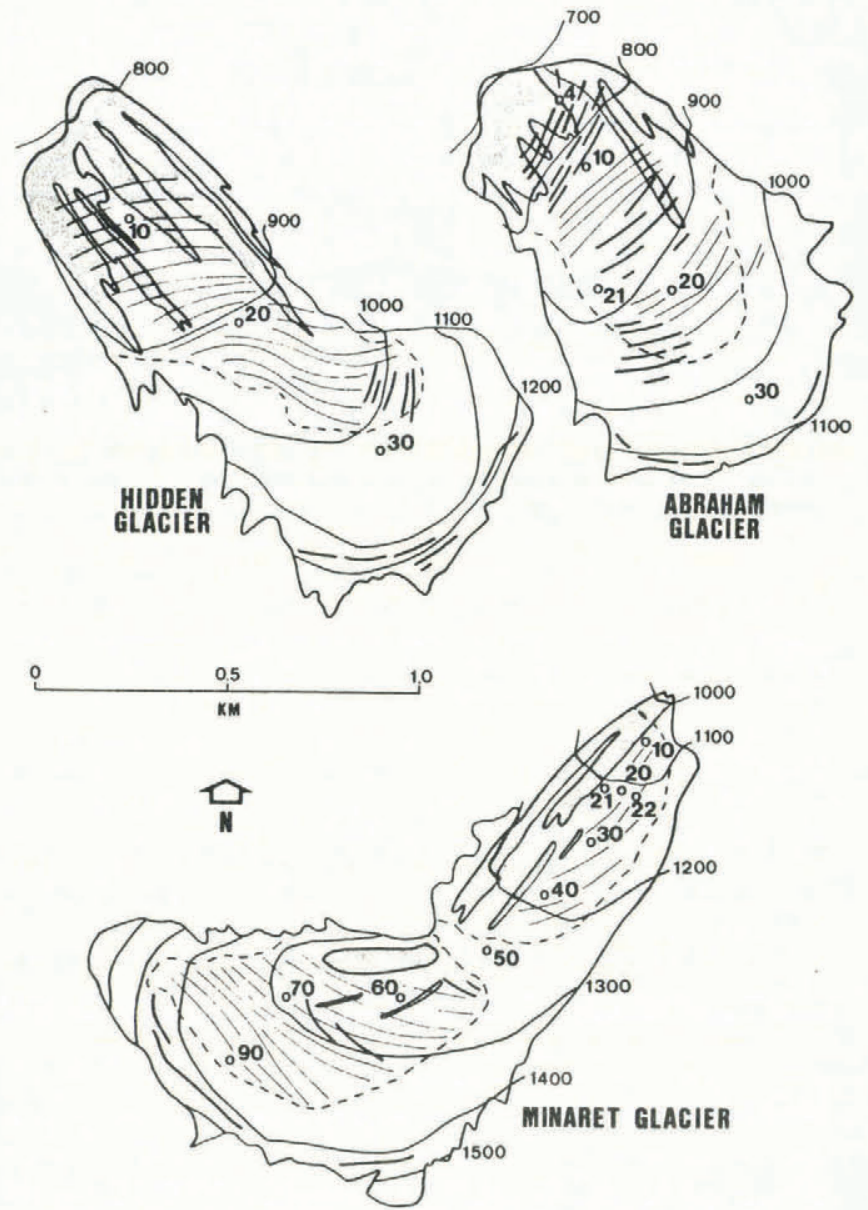

ApProximate Late su
Supraglacial oebris
(medial moraimes)

Fig. 3. Maps of medial moraines and typical late-season snow lines on Abraham, Hidden, and Minaret Glaciers.

compound form, are conditions appropriate for the formation of types of medial moraines other than the "avalanche type".

\section{SUPERGUKSOAK GLACIER MORAINES}

Numerous septa or longitudinally oriented debris bands appear on the ice surface below the mid- to late-season snow line and coalesce into four major medial moraines (Fig. 2). These moraines merge successively down-glacier to form an extensive supraglacial debris cover. The central medial moraine (III on Figure 2), contains the clearest morphology and is longer and higher than those on either side. The up-glacier end of the moraine reveals it is formed from at least five septa (Fig. 4), depending on the scale of observation, and sub-ridges on the moraine probably represent continuing debris supply from several of these same septa.

Late in the melt season, below the transient snow line, it can be observed that the septa have two specific and different relationships to flow units identified from deformation of primary (firn-bedding) structures on the glacier surface (Fig. 4). Those septa which define the junctions of flow units, type $x$ septa, must be derived subglacially from zones or points of junction between avalanche cones in the firn basin. Those which occur at or close to the centre of a flow unit, type $y$ septa, must be derived primarily from deposition of debris down couloirs in the firn basin. These couloirs are the major source of snow to the accumulation basin. At the end of the 1983 and 1984 melt seasons, most of the snow remaining on the glacier surface was close to the foot of each couloir. Debris in type $y$ septa is probably both bedded into the firn during avalanche events, and ingested by the firn via bergschrund-like crevasses which commonly occur in the lower parts of the couloirs. This latter process has been described by Osborn (1983) on avalanche-cone glaciers in the Canadian Rocky Mountains.

From the points at which the septa thicken to become dirt ridges, in the order of $1-3 \mathrm{~m}$ in breadth, the debris surface possesses distinct relief over the adjacent clean ice surface. This relief increases down-glacier relative to the clean ice, reaching a maximum on moraine III about $200 \mathrm{~m}$ from the glacier terminus, about three-quarters of the way down the moraine. By that point only a narrow exposure of clean ice, $11 \mathrm{~m}$ wide, remains on the eastern side of the moraine, while on the western side there is no clean ice exposed. The moraine is $120 \mathrm{~m}$ wide at this point (Fig. 2).

The contrast between the surface gradient of the moraine and that of the ice surface between the moraines is explained by the contrast in ice melt. In the summer of 1983,13 poles were read in the lower part of Superguksoak Glacier, three of which $(11,12$, and 25 on Figure 2) were located on the debris-covered ice of the medial moraines. For the period 11 July to 19 August 1983 , ice melt on debris-covered ice was only $35 \%$ of that on clean ice (Table I). This is similar to contrasts reported by Young (1953), Loomis (1970), and many subsequent workers.

Surface drainage of melt water is largely controlled by moraine relief. Streams flow parallel to the moraines but in the hollows between them. Subsequent melt and incision help emphasize moraine relief. In three locations, melt-water streams cut obliquely across medial moraines I and II, and the west lateral moraine in deeply entrenched courses. These may have been superimposed from an overlying snow cover,

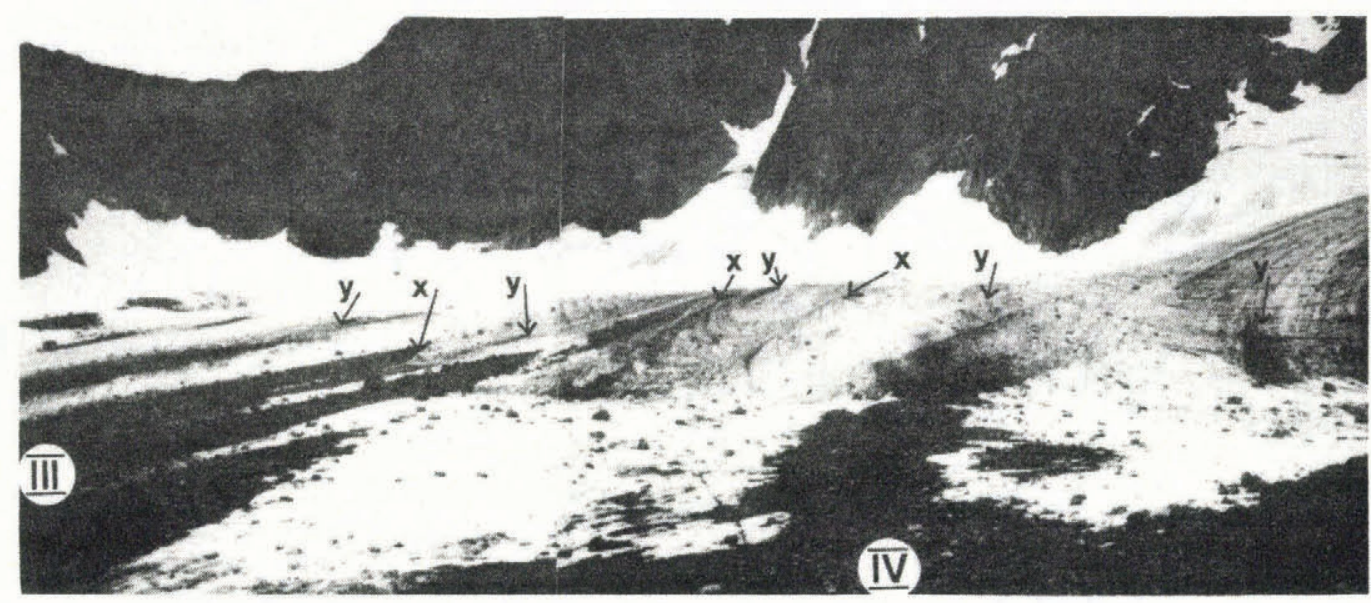

Fig. 4. Debris septa on the up-glacier parts of medial moraines III and IV. The type $x$ septa are formed at points of junction, while type y septa are formed from couloir deposition. 
TABLE I. ICE MELT ON SUPERGUKSOAK GLACIER, SUMMER 1983

(a) Ablation stakes on debris-covered ice

\begin{tabular}{|c|c|c|c|c|c|c|}
\hline \multirow[t]{2}{*}{ Stake No. } & Elevation & $\begin{array}{r}\text { Period } \\
\text { dates }\end{array}$ & Days & Ice melt & Rate & Rate w.e.* \\
\hline & $\mathrm{m}$ & 1983 & & $\mathrm{~cm}$ & $\mathrm{~cm} / \mathrm{d}$ & $\mathrm{cm} / \mathrm{d}$ \\
\hline 11 & 720 & $29 / 7-19 / 8$ & 21 & 41 & 1.95 & 1.76 \\
\hline 12 & 720 & $11 / 7-19 / 8$ & 39 & 23 & 0.59 & 0.53 \\
\hline$\underline{25}$ & $\underline{760}$ & $11 / 7-19 / 8$ & $\underline{39}$ & $\underline{63}$ & $\underline{1.62}$ & $\underline{1.45}$ \\
\hline Means & $\underline{730}$ & & $\underline{33}$ & $\underline{42}$ & $\underline{1.27}$ & $\underline{1.15}$ \\
\hline \multicolumn{7}{|c|}{ (b) Ablation stakes on "clean ice" } \\
\hline 10 & 700 & $11 / 7-19 / 8$ & 39 & 172 & 4.41 & 3.97 \\
\hline 20 & 750 & $11 / 7-19 / 8$ & 39 & 170 & 4.36 & 3.92 \\
\hline 21 & 750 & $11 / 7-19 / 8$ & 39 & 108 & 2.77 & 2.49 \\
\hline 22 & 755 & $29 / 7-19 / 8$ & 21 & 87 & 4.14 & 3.73 \\
\hline 23 & 760 & $11 / 7-19 / 8$ & 39 & 121 & 3.10 & 2.79 \\
\hline 30 & 820 & $11 / 7-19 / 8$ & 39 & 138 & 3.54 & 3.18 \\
\hline 31 & 830 & $11 / 7-19 / 8$ & 39 & 138 & 3.54 & 3.18 \\
\hline 32 & 825 & $30 / 7-19 / 8$ & 20 & 72 & 3.60 & 3.24 \\
\hline 33 & 825 & $27 / 7-19 / 8$ & 23 & 80 & 3.48 & 3.13 \\
\hline$\underline{40}$ & $\underline{850}$ & $13 / 7-19 / 8$ & $\underline{37}$ & $\underline{137}$ & 3.70 & $\underline{3.33}$ \\
\hline Means & $\underline{787}$ & & $\underline{33.5}$ & $\underline{122}$ & $\underline{3.66}$ & $\underline{3.30}$ \\
\hline
\end{tabular}

Rates for (a) are $35 \%$ of rates for (b).

$*_{\text {w.e. }}=$ water equivalent.

or be relict overflow channels to slush pools which were common in 1981 and may be important features during any melt season following a large accumulation of snow.

In 1981, a line of 24 surface markers along the centre of moraine III was surveyed and subsequently re-surveyed later that summer and in 1982 and 1983. Down-glacier displacement of the markers was very slight, amounting to a maximum of $2.4 \mathrm{~m}$ in $1981-82$ and $8.1 \mathrm{~m}$ in $1982-83$ at marker 24 (Fig. 5). Thus, slight longitudinal compressive strain is present, although it may not be a major influence on moraine morphology.

\section{SEDIMENTS}

As elsewhere (e.g. Eyles and Rogerson, 1978[b]) medial moraine sediments are very coarse, consisting of boulders, gravel, and some coarse sand, and very angular.

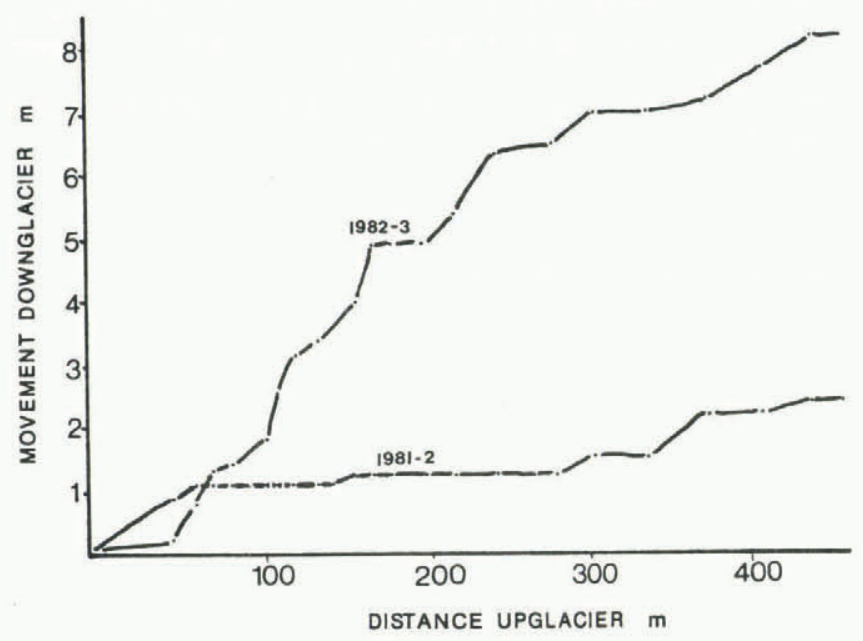

Fig. 5. Down-glacier movement of surface markers on the lower part of medial moraine III on Superguksoak Glacier.
Bedrock forming the backwall of the cirque is of three major types: gneiss and anorthosite with some mafic intrusives (Wardle, 1983). All types of bedrock are deformed in steeply dipping north-south structures and tend to break into tabular blocks with two parallel surfaces. Where the moraine septa first appear, the larger blocks form glacier tables with ice pedestals. Towards the terminus, the blocks lie parallel to the surface forming a pavement-like cover Medial moraine IV is composed almost entirely of dark, mafic blocks and therefore can be traced to the area of the cirque backwall where a mafic outcrop occurs in the vicinity of Western Couloir.

\section{MORAINES ON MINARET, HIDDEN, AND ABRAHAM GLACIERS}

Unlike Superguksoak Glacier, most other glaciers in the Torngat Mountains are simple cirque glaciers with a single ice-flow unit generated in a single firn basin. On Minaret Glacier, net accumulation is greatest against the eastern wall, while on Hidden and Abraham Glaciers it is greatest against the western wall (Fig. 3). Debris septa are predominantly type $y$, formed from avalanche debris delivered to the firn via couloirs. Some potential exists for forming type $x$ septa between avalanche cones but no major confluence occurs for generating large "ablation-dominant" or "ice-stream interaction" medial moraines. The septa thicken to form two medial moraines on Minaret Glacier, both skewed towards the western side of the glacier. On Hidden and Abraham Glaciers, septa first appear close to the glacier snouts and abruptly thicken to form several short moraine ridges which coalesce less than $100 \mathrm{~m}$ down-glacier, making virtually continuous aprons of sediment. The debris becomes a supraglacial facies, equivalent to facies B, supraglacial morainic till (Eyles, 1979) in the terminal moraines formed by the glaciers. In the case of Abraham Glacier, a distinct, ridged terminal moraine is being formed along a part of the snout which has re-advanced consistently since 1981. The terminus moved forward an average of $1.2 \mathrm{~m} /$ year for the period 1981 to 1984 , based on measurements at four sites. 


\section{CONCLUSION AND DISCUSSION}

Medial moraines may form in glaciers which are not nourished from compound firn basins, nor have junctions with other ice streams either above or below the firn line. Most of these moraines are formed of debris which is delivered to the glacier down couloirs, bedded in firn layers or ingested by crevasses, and subsequently exposed down-glacier as overlying firn and ice is melted. In morphological respects, the moraines formed are not recognizably different from the "ablation-dominant" type of medial moraines and merge with septa of that origin on the surface of Superguksoak Glacier. Relief develops on the moraine surfaces in the same way it develops on "ablationdominant" types due to retarded rates of ice melt. The similarities and close association between these two types, particularly on Superguksoak Glacier, suggest that the term medial moraine is appropriate for both rather than only for the "ablation-dominant" type.

The moraines fall within the general description of the "avalanche-type model" (Eyles and Rogerson, 1978[a]), which must be regarded not as a minor model but as the most important type of medial moraine forming on Torngat Mountains glaciers.

Avalanche-type medial moraines, nourished by sediments fed down couloirs, may be expected on glaciers where the walls of the confining cirque are high. Since the presence of extensive supraglacial debris reduces ice melt in the ablation zone, the medial moraines may be regarded as an important factor in the mass balance of such glaciers. Both the amount of shading of the glacier surface and the amount of sediment delivered to the glacier are likely to increase as the glacier-surface elevation is reduced in response to long periods of negative mass balances. Both of these factors increase directly with the relative height of the cirque backwall and the length of its associated couloirs, and probably inversely affect the amount of surface melt. Theoretically, this negative feed-back relationship may be responsible for the survival of small ice masses in deep cirques during sustained periods of climatic warmth. With reference to the cirque glaciers of the Torngat Mountains, it raises the specific question: was this effect of sufficient magnitude to allow these glaciers to persist, much reduced in size, through the post-glacial hypsithermal interval in Labrador (c. 6-3 ka B.P.)? Further research is needed to answer this question.

\section{ACKNOWLEDGEMENTS}

This research was supported by Canadian Natural Sciences Engineering Research Council operating grants A6105 to R.J. Rogerson as part of a larger project on the glaciers and glacial geology of the Torngat Mountains. Dr R. Wardle and B. Ryan of the Newfoundland Department of Mines and Energy, PetroCanada Explorations, and H.A. Williamson of the Memorial University's Labrador Institute assisted with logistics. H. Russell and L. St. Croix, supported by Northern Scientific Training Grants from the Department of Indian Affairs and Northern Development, were excellent assistants in the field, and diagrams were drafted by S. Halliday.

\section{REFERENCES}

Branson, D. Unpublished. Magnitude and characteristics of ablation on four Torngat glaciers. [B.A. Hons dissertation, University of Cambridge, 1984.

Drewry, D.J. 1972. A quantitative assessment of dirt-cone dynamics. Journal of Glaciology, Vol. 11, No. 63, p. 431-46.

Eyles, N. 1979. Facies of supraglacial sedimentation on Icelandic and Alpine temperate glaciers. Canadian Journal of Earth Sciences, Vol. 16, No. 7, p. 1341-61.

Eyles, N., and Rogerson, R.J. 1978[a]. A framework for the investigation of medial moraine formation: Austerdalsbreen, Norway, and Berendon Glacier, British Columbia, Canada. Journal of Glaciology, Vol. 20, No. 82, p. 99-113.

Eyles, N., and Rogerson, R.J. 1978[b]. Sedimentology of medial moraines on Berendon Glacier, British Columbia, Canada: implications for debris transport in a glacierized basin. Geological Society of America. Bulletin, Vol. 89, No. 11 , p. $1688-93$

Lliboutry, L. 1965. Traité de glaciologie. Tome II. Glaciers, variations du climat, sols gelés. Masson, Paris, Masson et Cie.

Loomis, S.R. 1970. Morphology and ablation processes on glacier ice. (In Bushnell, V.C., and Ragle, R.H., eds. Icefield Ranges Research Project. Scientific results. Vol. 2.

New York, American Geographical Society; Montreal, Arctic Institute of North America, p. 27-31.)

Ogilivie, I.H. 1904. The effect of superglacial debris on the advance and retreat of some Canadian glaciers. Journal of Geology, Vol. 12, p. 722-43.

Osborn, G. 1983. Characteristics of the bergschrund of an avalanche-cone glacier in the Canadian Rocky Mountains. Journal of Glaciology, Vol. 29, No. 101, p. 55-69.

Östrem, G. 1959. Ice melting under a thin layer of moraine, and the existence of ice cores in moraine ridges. Geografiska Annaler, Vol. 41, No. 4, p. 228-30.

Rogerson, R.J., and Eyles, N. 1979. Berendon Glacier medial moraines: their form, sediments, and terminal ice melt effects. St. John's, Memorial University of Newfoundland. Department of Geography. (Research Note 4.)

Salisbury, R.D. 1894. Superglacial drift. Journal of Geology, Vol. 2, No. 6, p. 613-32.

Sharp. R.P. 1949. Studies of superglacial debris on valley glaciers. American Journal of Science, Vol. 247, No. 5, p. 289-315.

Small, R.J., and others. 1979. The formation of medial moraines on Alpine glaciers, by R.J. Small, M.J. Clark, and T.J.P. Cawse. Journal of Glaciology, Vol. 22, No. 86, p. 43-52.

Wardle, R.J. 1983. Nain-Churchill Province cross-section, Nachvak Fiord, northern Labrador, 1983. St. John's, Government of Newfoundland and Labrador. Department of Mines and Energy, p. 68-90. (Report 83-1.)

Young, R.A. 1953. some notes on the formation of medial moraines. Jökull, Ár 3, p. 32-33. 